\title{
Inquiry Based Lesson Study to Improve Students' Activity in Learning Biology
}

\author{
Dini Siswani Mulia, Arief Husin, and Cahyono Purbomartono \\ Department of Biology Education, Teacher Training and Education Faculty \\ Universitas Muhammadiyah Purwokerto \\ Indonesia
}

\begin{abstract}
This lesson study was aimed at improving students' activity through inquiry learning model on General Biology subject. It was conducted in odd semester of academic year 2012/2013, for the first semester students at Class A on General Biology subject, Department of Biology Education, Universitas Muhammadiyah Purwokerto. The subjects of this lesson study were students taking General Biology subject from class A; they were 30 persons consisting of 23 female students, and 7 male students. The learning process included four basic actions correlated and continued each other in each cycle; the actions were: (1) planning, (2) acting, (3) observing, and (4) reflecting. It was conducted in four cycles. The result of lesson study showed the dynamics of achievement score of student activity in learning. In cycle I, the score reached 625 with only one indicator that was scored good (group 5) the discussion activity that was, then it increased in cycle II; the score was 750, with good indicator. It was discussion activity (groups 1, 3, and 4) and the ability to argue (groups 1 and 2). However, in cycle III there was a decrease with its score little bit higher than the score in cycle I (650), and a well-categorized indicator was discussion activity (group 1). In cycle IV it increased again, and reached the highest score, that was 775 and the indicator categorized very well was the discussion activity (groups 2 and 4), and the ability to argue (group 4) with good category. Based on the result of lesson study, it can be concluded that the inquiry model in General Biology material can improve student learning activity in the class.
\end{abstract}

Keywords: student activity, inquiry learning model, general biology.

\section{Introduction}

Teaching and learning material of Biology subject in its discussion is related to how to find out a living concept and the life in a systematic way, so that learning materials of Biology subject do not only emphasize mastery of knowledge in form of facts, concepts, or principles, but also a process of discovery and investigation in its learning. Biology learning does not not only emphasize skill process, but also on the student's ability-based activity.

There are several things that need to be considered in Biology learning in accordance with the characteristics of Biology science. The characteristics are: (1) biology has the object of study in the form of realistic objects, namely organisms; (2) it is developed based on real experience; and (3) it used logical and objective thought, not memorizing (Santoso, 2005 dalam Wulandari, 2008).

The learning material of General Biology subject for the first students of Biology Education Department. As the freshman, the students are in transition phase in between senior high education and higher education (college). It affects the students' learning activity in the classes. In the beginning of their study at colleges, they tend to be passive, only some of them who are active in learning activity. The oportunity to have question and answer session should be offered many time, so they finally ask questions to the lecturers. The students usually only focuses on the lecturer's explanation with no response in General Biology subject. They tend not to prepare their study at their homes, so their are lack in the learning activity.

Therefore, it is necessary to set a way of learning model that can improve students' mastery of biology learning materials and their ability to think logically, critically, creatively, and can improve students' activity for discussing and arguing properly. The lecturers do not take a dominant role in the learning activity, but give the students more opportunity to involve and to be more active in the learning activities. One of learning models to optimize the learning activity is inquiry learning model. The students are set to discover, observe, and conclude a concept. In addition, their active in the learning process can be improved.

The inquiry learning model is one of the learning approaches that can improve students' activity and their understanding on materials of General Biology subject. It is a learning approach that can help students to relate between material taught and daily realistic-world situatios (Trianto, 2007). The inquiry learning model can develop analytical skills and create an interaction between concepts owned by the students, and the findings or new evidence they have learned, so 
it can provide a better understanding of the concept (Agustina, 2010).

In this model, students should cooperate each other to solve learning problems. Thy do not directly get the explanation from the lecturers. The lecturers play their role as facilitators, not as a knowledge provider. The principles of this learning model is oriented on intellectual development, interaction, asking, learning to think, and openness. The teaching model changes from 'teacher centered' to 'student centered' (Udin, 2005).

Aris (2012) conducted a classroom action research using inquiry method to improve students' learning outcome of Natural Science subject for fourth grade students of primary schools. The result showed that the learning process of Natural Science subject run actively; the students interacted each other in the learning process. In its pre-cycle, the class average score was 58.5 with learning completeness $40 \%$, in cycle 1 , it improved 72 and $70 \%$. In cycle 2 , it became 82 with completeness $90 \%$.

Astuti (2010) was successful to improve third grade students' learning achievement SDN 02 Lemahbang Jumapolo Karanganyar with inquiry learning model. Previosuly, its learning completeness was $27.27 \%$, then it increased to $81.81 \%$. In addition, this learning model was also able to improve the studnts' learning activity of Natural Science lesson. It was proven in cycle 1 , the students who were active to prepare equipments and materials for the observation activity were $68.18 \%$, in cycle 2 it increased to $63.63 \%$, in cycle 3 it increased again to $80.81 \%$. In order, the steps of trial in cycle 1 was $77.27 \%$, in cycle 2 it was $77.27 \%$, and in cycle 3 it increased to $95.45 \%$. The activities of trial in cycle 1 achieved $50 \%$, in cycle 2 it was $72.72 \%$, and in cycle 3 it was $77.27 \%$. Students' cooperation in discussion activity in cycle 1 was $77.27 \%$, in cycle 2 it was $81.81 \%$, and in cycle 3 it was $86.36 \%$, while in concluding ability, it was $72.73 \%$ in cycle $1,86.86 \%$ in cycle 2 , and siklus $90.90 \%$ in cycle 3 .

Based on the background this lesson study will focus on improving students' activity on General Biology learning using Inquiry model.

\section{Method}

This research employed lesson study through a classroom action using Inquiry learning model. The learning process included four basic actions correlated and continued each other in each cycle; the actions were: (1) planning, (2) acting, (3) observing, and (4) reflecting. It was conducted in four cycles.

\section{Result and Discussion}

Inquiry based learning model is able to improve students' learning activity. (Table 1). In the table, tersaji rekapitulasi skor dari 3 indikator aktivitas mahasiswa selama 4 siklus.

Table 1. The score recapitulation of students' learning activity in cycle 1-4

\begin{tabular}{|c|c|c|c|c|c|}
\hline No & Group & Cycle 1 & Cycle 2 & Cycle 3 & Cycle 4 \\
& & & & & \\
\hline 1 & $\mathbf{1}$ & 150 & 175 & 150 & 125 \\
\hline 2 & $\mathbf{2}$ & 125 & 150 & 125 & 200 \\
\hline 3 & $\mathbf{3}$ & 100 & 175 & 125 & 125 \\
\hline 4 & $\mathbf{4}$ & 125 & 125 & 125 & 200 \\
\hline 5 & $\mathbf{5}$ & 125 & 125 & 125 & 125 \\
\hline & Total & 625 & 750 & 650 & 775 \\
\hline
\end{tabular}

Learning by inquiry model can encourage students to be active in learning. LKM (Student Activity Sheet) are structured with questions and drawings that can motivate them to discover, and observe a biological concept. In this learning model, learning process cannot be separated from activity and interaction, students are encouraged to actively ask. In addition, the students will be faced with a problem that must be observed, studied, and scrutinized, which finally can improve understanding of the concept of course (subject) in learning activities.

In this inquiry model, students also discussed results of the observation, so it can motivate students to actively talk, ask questions, argue, and make conclusions. They can freely express their ideas, without fear to make mistakes, freedom of expression, respect for the opinions of others, confess their opinions wrongly and acknowledge the opinions of others to achieve a scientific truth.

Discussion groups were divided into 5 groups, and each group consisted of 6 members. The selection of group leader was based on data of students' activeness; the student who was active in general biology subject was selected as the group leader. It was done before the lesson study activity was conducted, while the division of group members was done randomly, because previously each student's potential was not known, because the students taking this subject were the first semester students.

The recapitulation result on table 1 showed that the highest score was achived in cycle 4 , it was 775. In cycle 1 , the score was just 625 , then it increased in cycle 2 , it was 750 , but it decreased in cycle 3 (650), and incresed again in the last cycle. The increase from cycle 1 to cycle 2 was because the students were accustomed with the learning model, so they could respond properly. In cycle 1, the well categorized indicator was only in discussion activity (group 5), while in cycle 2, the well categorized indicator was discussion activity (group 1, 3, and 4) and arguing ability (group 1 dand 2). But, in cycle 3 it decreased to 650 , and the well categorized indicator was discussion activity (group 1). It was predicted 
because the learning material in cycle 3 was quite difficult rather than the material in cycle 1 and 2 . The increase of students' learning activity in cycle 4 occured because the students have been accustomed and able to adjust their-selves to Inquiry based learning model and discussion method. Although there were many aspects should be fixed to be better. The very well categorized indicator was discussion activity (group 2 and 4), and arguing ability (group 4) with good category.

Table 2. The data of good/excellent indicator of each cycle

\begin{tabular}{|c|c|c|c|c|c|}
\hline \multirow{2}{*}{ No } & \multirow{2}{*}{ Indicators } & \multicolumn{4}{|c|}{ Cycle/Group } \\
\hline & & I & II & III & IV \\
\hline 1 & $\begin{array}{l}\text { Discussion } \\
\text { Activity }\end{array}$ & $+/ 5$ & $+/ 1,3$, and 4 & $+/ 1$ & +2 dan 4 \\
\hline 2 & $\begin{array}{l}\text { Arguing } \\
\text { ability }\end{array}$ & & $+/ 1$ and 2 & & +4 \\
\hline 3 & $\begin{array}{l}\text { Concluding } \\
\text { ability }\end{array}$ & & & & \\
\hline & Total & 625 & 750 & 650 & 775 \\
\hline
\end{tabular}

Based on the data of good/excellent indicators, discussion activity was in group 1, 2, 3, 4, and 5 (table 2). Indicator of studnets' arguing ability was in group 1, 2, and 4. According to Sanjaya (2010), learning in team/group can encourage students to share information and opinions, discuss common problem solving, compare their answers and correct things that were not quite right. Thus students will be more active to communicate, and from the communicating ability, they will be able to understand better about the issues to be solved. The discussion method can improve thinking and arguing ability (Faizin, 2009).

Table 2 showed that indicator of concluding ability was not quite good. It was predicted because the first semester students were not accustomed to conclude a learning material properly. Material limitations, understanding, and learning experience in higher education (college) were also thought to affect that. However, the steps of lesson study activities in semester 1, was expected to trigger the spirit and motivate the students to be able to develop themselves in learning, and active in learning in the next courses.

\section{Conclusion and Suggestion}

Based on result of this lesson study, it can be concluded that Inquiry based learning model on General Biology learning material can improve students' learning activity in the classes. The highest increase was achieved in cycle 4 with very well (excellent) category in discussion activity, well categorized arguing ability.

The researchers suggested to conduct continuous lessons study in order to obtain better quality of learning which has implications for increasing student learning activity and increasing their understanding.

\section{References}

Agustina, F. 2010. Peningkatkan Pemahaman Konsep Biologi Menggunakan Model Pembelajaran Discovery-Inquiry pada Siswa Kelas X-3 SMA Negeri 4 Purwokerto. Skripsi. Program Studi Pendidikan Biologi, Fakultas Keguruan dan Ilmu Pendidikan, Universitas Muhammadiyah Purwokerto. Purwokerto.

Aris, A. 2012. Penerapan Metode Inkuiri untuk Meningkatkan Hasil Belajar Ilmu Pengetahuan Alam pada Siswa Kelas IV. Skripsi. Universitas Kristen Satya Wacana.

Astuti, M.D. 2010. Peningkatan Prestasi Belajar IPA Melalui Model Pembelajaran Inkuiri Siswa Kelas III SDN 02 Lemahbang Kecamatan Jumapolo Kabupaten Karanganyar Tahun 2009 / 2010. Skripsi. Universitas Negeri Sebelas Maret. Surakarta.

Faizin, S. 2009. Efektivitas Diskusi dalam Meningkatkan Kemampuan Berpikir dan Berpendapat (Studi Kasus pada Pembelajaran Civic Society di IAI Nurul Jadid Paiton Probolinggo). Jurnal Pendidikan Islam. Vol 1 No1 :42-49.

Sanjaya. 2010. Perencanaan dan Desain Sistem Pembelajaran. Jakarta: PT.Fajar Interpratama.

Trianto, 2007. Model-model Pembelajaran Inovatif berorientasi Konstruktivistik. Surabaya : Prestasi Pustaka.

Tuminah. 2012. Meningkatkan Aktivitas Belajar Ilmu Pengetahuan Alam Melalui Model Pembelajaran Inkuiri pada Materi Cahaya di Kelas VIIIE SMP Negeri 1 Sampang, Cilacap Tahun Pelajaran 2011/2012. Skripsi. Program Studi Pendidikan Biologi, Fakultas Keguruan dan Ilmu Pendidikan, Universitas Muhammadiyah Purwokerto. Purwokerto.

Udin S. Winataputra, 2005, Model-Model Pembelajaran Inovatif, Edisi Revisi, PAUPPAI. Universitas Terbuka, Jakarta.

Wulandari, B. 2008. Pengaruh Model Pembelajaran Kooperatif Tipe TGT Terhadap Peningkatan mata Pelajaran Biologi Siswa kelas X SMA N 1 Kemangkon Kabupaten Purbalingga. Skripsi. Program Studi Pendidikan Biologi, Fakultas Keguruan dan Ilmu Pendidikan, Universitas Muhammadiyah Purwokerto. Purwokerto. 